\title{
A Case Study on the Impact of Web-based Technology in a Simulation Analysis Course
}

\author{
Mary Court \\ Associate Professor \\ University of Oklahoma \\ School of Industrial Engineering \\ 202 W. Boyd, Suite 124 \\ Norman, OK 73019 \\ Telephone: (405) 325-4341 \\ e-mail: mcourt@ou.edu
}

A case study is presented on the use of web-based technology to transition from a lecture-based delivery system to an online/multimedia technology delivery system at the University of Oklahoma's School of Industrial Engineering. Coupling web and multimedia technology with a pyramid approach to a simulation course sequence, the goal is to provide both undergraduate and graduate students with strong simulation skills in both modeling analysis. Web-based technology is used to provide course. access to non-traditional students, to re-enforce prerequisite knowledge, and to support learning statistical concepts. The approach has been successful at (i) generating two types of graduates, the simulation modeler and the simulation analyst/consultant, (ii) increasing the retention of non-traditional students (industrial engineering students with full-time jobs and other engineering majors without strong statistical backgrounds), and (iii) graduating two non-traditional students in the School's master's degree program as based on their research in simulation analysis. However, online technologies are not without their disadvantages. While the burden has b eased on student learning and their out-of-class activttes,? the faculty is now tasked with an increased load of supporting online courses and utilizing web-based techn gies both within and outside the classroom.

Keywords: Web-based technology, multimedia technology, non-traditional students, simulation modeler, simulation analyst/consultant, simulation developer, industrial engineering

\section{Introduction}

Several factors influenced the decision to implement web-based technology when delivering simulation courses at the University of Oklahoma. First, the trend in engineering education is to require more and more computer usage in the classroom. In fact, many of the top-ranked US engineering colleges have instituted laptop programs for their undergraduate curricula. The general opinion is that laptop computing environments support collaborative, group and cooperative approaches to learning, provide faculty with the means to develop innovative teaching methodologies, and improve the efficiency of the delivery system by providing "anytime, anywhere" course access. In 1998, the College of Engineering (COE), at the University of Oklahoma, implemented a wireless laptop program throughout all undergraduate courses. Consequently, faculty were required to teach undergraduate courses via wireless laptops in wireless rooms. Secondly, the National Science Foundation has placed strong emphasis on requiring funded researchers to incorporate research into the classroom and to attract and retain underrepresented students. Thus, there have been increased efforts in recruiting and retaining engineering students, particularly minority engineering students. Fortunately at $\mathrm{COE}$, the trend for the 
minority population has been increasing. Twenty-six percent (up from twenty-one percent in 1995) of COE's engineering student body is minority and $96 \%$ are retained. As a result of the increased percentages of minority engineering students, engineering schools are taking a very proactive view in redesigning and or developing engineering undergraduate courses aimed at retention. Studies have shown that most female students prefer and take a more active role in creative, cooperative learning activities $[1,2]$ and that AfricanAmerican and Mexican-Americans also perform better in cooperative-learning environments $[3,4]$. Thirdly, the School of Industrial Engineering's Undergraduate Curriculum Committee, Industrial Engineering Advisory Board and alumni identified simulation modeling as a critical job skill for all industrial engineering graduates. In 1995, the School's simulation course sequence was redesigned to meet that need. The goal was to produce three types of graduates:

1. Simulation modeler, one who is capable of applying a simulation language for the purpose of analyzing, designing and comparing systems.

2. Simulation analyst/consultant, one who can conduct a simulation study and perform simulation input and output analysis.

3. Simulation developer, one who is capable of developing simulation language logic and code.

All of these factors necessitated the addition of simulation courses and the development of fundamental modeling courses. However, the goal was to minimize the number of new courses that needed to be developed by implementing computers and web-based technology in the classroom. The idea was that if interactive learning was utilized in the classroom, students would grasp concepts more quickly than in a traditional classroom environment. In addition, the use of online tutorials would reduce the amount of time spent on reviewing prerequisite material during class, by shifting the responsibility for that knowledge onto the student (where it belongs).

The intrinsic consequences of switching from a traditional, lecture-based delivery system to an online/ web-based classroom are changes in how the courses are designed and taught. The web-based classroom allows faculty to bring real-world problems into the classroom, a desired teaching mechanism for most simulation courses. A natural extension to bringing real-world applications into the classroom is that faculty now have the capability of emphasizing model validation techniques in lower-level simulation courses.

A case study on the evolution of a simulation course from a traditional, lecture-based delivery system to an online/web-based course delivery system is presented. An overview of the simulation sequence that the course supports and the course descriptions are provided, along with a discussion of how the course was taught in the past versus how it is taught today (including in-class and out-of-class activities). The technology employed and the workload for utilizing the technology are also reviewed. Finally, the impact of web-technology is discussed in terms of problems solved and problems created for both faculty and students.

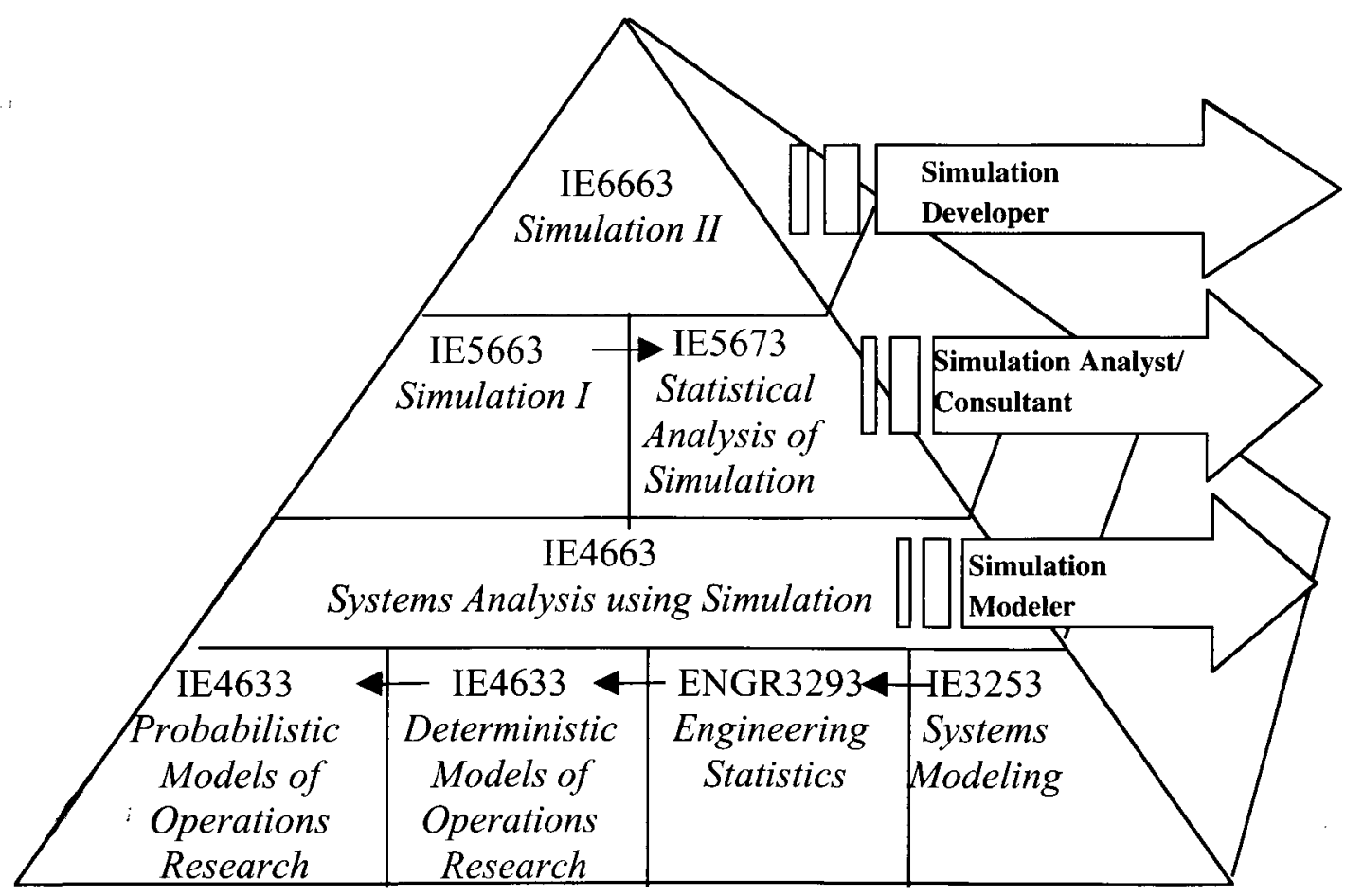

Figure 1. Pyramid approach to simulation courses, Fall 1996 
Table 1. Course delivery system, Fall 1993

\begin{tabular}{|c|c|c|c|c|c|}
\hline $\begin{array}{c}\text { Classroom } \\
\text { Type }\end{array}$ & $\begin{array}{l}\text { Instructor's } \\
\text { Role }\end{array}$ & $\begin{array}{c}\text { Teaching } \\
\text { Assistant's Role }\end{array}$ & $\begin{array}{c}\text { Students' } \\
\text { In-Class } \\
\text { Activities }\end{array}$ & $\begin{array}{c}\text { Students' } \\
\text { Out-of-Class } \\
\text { Activities }\end{array}$ & $\begin{array}{c}\text { Technology } \\
\text { Used in } \\
\text { Classroom }\end{array}$ \\
\hline $\begin{array}{c}\text { Traditional, } \\
\text { Lectern }\end{array}$ & \begin{tabular}{|l|} 
In-class: \\
-Present an \\
overview of \\
topics and \\
examples \\
-Conduct \\
exams \\
Out-of-Class: \\
-Office hours \\
-Design exams \\
-Grading \\
-Graduate \\
students: \\
design \\
projects and \\
teams
\end{tabular} & $\begin{array}{l}\text { In-class: } \\
\text {-Assist in } \\
\text { proctoring } \\
\text { exams } \\
\\
\text { Out-of-class: } \\
\text {-Office hours } \\
\text {-Address } \\
\text { software issues } \\
\text {-Grading }\end{array}$ & $\begin{array}{l}\text {-Note taking } \\
\text {-Take exams }\end{array}$ & $\begin{array}{l}\text {-Read the book } \\
\text {-Learn } \\
\text { simulation } \\
\text { software } \\
\text {-Complete } \\
\text { homework } \\
\text { assignments } \\
\text {-Go to office } \\
\text { hours for } \\
\text { assistance } \\
\text {-Graduate } \\
\text { students: meet } \\
\text { with team for } \\
\text { design project }\end{array}$ & $\begin{array}{l}\text {-Chalkboard } \\
\text {-Overhead } \\
\text { projector }\end{array}$ \\
\hline
\end{tabular}

\section{A New Web-based Simulation Pyramid}

Figure 1 displays the new simulation course sequence as revised in Fall 1995 and implemented in Fall 1996. The simulation sequence can be viewed as a pyramid of knowledge, where each level is supported by webtechnologies in order to produce one of the three desired graduates: simulation modeler, simulation analyst/consultant, and simulation developer. The lowest level of the pyramid depicts the prerequisite courses for the simulation sequence. Tables 1 and 2 represent the impact of adopting the pyramid approach. Essentially, the two simulation courses offered in Fall 1993 were traditional classroom environments where the instructor taught, students took notes, and computer/ simulation programming was performed as an outof-class activity (Table 1).

The current sequence now involves four simulation courses taught in an online/multimedia classroom with access to the world-wide-web, simulation software packages (AWESIM and ARENA), other computer packages (Visual Basic and Visual C), and Microsoft Office 2000 (Word, Excel, PowerPoint, Excel and Access). Now, the instructor presents an overview of topics (via the world-wide-web or PowerPoint slides) and guides the class through inclass activities (Table 2). A description of the current simulation courses' content is found in Table 3. Topics in Table 3 that are in boldface type indicate new topics not previously covered by the past simulation sequence.

\section{Advantages of Web-based Technologies}

Of the four simulation courses, Statistical Analysis of Simulation (IE5573) has the most web tools support- ing its delivery. The web technology employed includes:

1. Online tutorials for prerequisite knowledge

2. Online quizzes for prerequisite knowledge

3. Online quizzes to re-enforce new knowledge

4. Chat rooms and e-mail for communication between the instructor and students and among the students

5. Online lecture notes and homework assignments

6. Online submission for homework and exams

7. Online exams

8. Excel macros for downloading applications and software

9. Video clips of systems for data collection and analysis

Topics that are now online include:

1. Probability functions

2. Random variates

3. Central limit theorem

4. $M / M / 1$ queuing systems

5 . Random variate generation

6. Manual simulations

7. Discrete-event simulations

8. Tests of ndependence (run tests, autocorrelation and scatter plots)

9. Fitting distributions to data (box plots, p-p plots, q-q plots, descriptive statistics, histograms, distribution functions, Chi-square tests, K-S tests, parameter estimation)

10. Terminating system analysis

11. Non-terminating system analysis (transient analysis, batch means method, independent replications, classical regenerative method) 
Table 2. Course delivery system, Present (since Fall 1996)

\begin{tabular}{|c|c|c|c|c|c|}
\hline \begin{tabular}{|c|} 
Classroom \\
Type
\end{tabular} & Instructor's Role & $\begin{array}{c}\text { Teaching } \\
\text { Assistant's } \\
\text { Role }\end{array}$ & $\begin{array}{l}\text { Students' } \\
\text { In-Class } \\
\text { Activities }\end{array}$ & $\begin{array}{c}\text { Students' } \\
\text { Out-of-Class } \\
\text { Activities }\end{array}$ & $\begin{array}{l}\text { Technology } \\
\text { Used in } \\
\text { Classroom }\end{array}$ \\
\hline $\begin{array}{c}\text { Online / } \\
\text { web-based }\end{array}$ & $\begin{array}{l}\text { In-class: } \\
\text {-Present an } \\
\text { overview of topics } \\
\text {-Train the students } \\
\text { in software } \\
\text { language / appli- } \\
\text { cations } \\
\text {-Guide students } \\
\text { through problem- } \\
\text { solving exercises } \\
\text { using the software } \\
\text {-Address software } \\
\text { and hardware } \\
\text { issues } \\
\text {-Conduct } \\
\text { computer-based } \\
\text { exams utilizing the } \\
\text { software } \\
\text { Out-of-class: } \\
\text {-Office hours } \\
\text {-Online office hours } \\
\text {-Answer e-mail } \\
\text {-Develop online } \\
\text { tutorials } \\
\text {-Develop web- } \\
\text { pages for course } \\
\text { content } \\
\text {-Develop language } \\
\text { independent/ } \\
\text { spreadsheet } \\
\text { programs and } \\
\text { applications } \\
\text {-Design online } \\
\text { exams } \\
\text {-Grade exams } \\
\text { online }\end{array}$ & $\begin{array}{l}\text { In-class: } \\
\text {-Assist in } \\
\text { proctoring } \\
\text { exams } \\
\text {-Assist in } \\
\text { software } \\
\text { training in the } \\
\text { classroom } \\
\text {-Conduct labs } \\
\\
\\
\text { Out-of-class: } \\
\text {-Office hours } \\
\text {-Online office } \\
\text { hours } \\
\text {-Answer e- } \\
\text { mail }\end{array}$ & $\begin{array}{l}\text {-Solve in-class } \\
\text { problems and } \\
\text { assignments } \\
\text {-Take online } \\
\text { exams }\end{array}$ & $\begin{array}{l}\text {-Read the book } \\
\text {-Learn } \\
\text { simulation } \\
\text { software } \\
\text {-Use on-line } \\
\text { tutorials } \\
\text {-Take on-line } \\
\text { quizzes } \\
\text {-Complete } \\
\text { homework } \\
\text { assignments } \\
\text {-Go to office } \\
\text { hours for } \\
\text { assistance } \\
\text {-Send e-mail } \\
\text { for assistance }\end{array}$ & $\begin{array}{l}\text {-PC lectern } \\
\text { with Elmo, } \\
\text { CD-ROM and } \\
\text { VCR } \\
\text {-PC's for each } \\
\text { student } \\
\text {-ARENA } \\
\text { professional } \\
\text { license on the } \\
\text { network } \\
\text {-AWESIM } \\
\text { professional } \\
\text { license on the } \\
\text { network } \\
\text {-World-wide- } \\
\text { web access via } \\
\text { Internet } \\
\text { Explorer } 5.0 \\
\text {-Visual Basic } \\
\text {-Visual C } \\
\text {-MSOffice2000 } \\
\text { Professional } \\
\text { Version }\end{array}$ \\
\hline
\end{tabular}

Offering the online topics by incorporating web-based technologies has resulted in the following advantages and observations:

1. Students have access to the course 24-hours a day, 7 days a week. Thus, absences from class have lesser consequences. In fact, students do not need to be present for exam times and can opt to take exams off-site, through a virtual bluebook. About $10 \%$ of the students opt to take their exams off-site.

2. The learning curve has been reduced when introducing new software to the classroom and it is now an in-class activity (in the past, the learning software was an out-of-class activity). As a result, a 50\% reduction has taken place in the amount of time required to cover basic simulation language commands.

3. Team assignments have realized better synergy and communication skills via online chat rooms and the e-mail system. In fact, there has been a $100 \%$ reduction in late assignments.

4. Output analysis topics such as non-terminating system analysis has realized a $30 \%$ reduction in the amount of class time required to cover this topic. In addition, the assignments on this topic have realized a $10 \%$ increase in the average grade.

5. Non-traditional students (industrial engineering students with full-time jobs and other engineering majors without strong statistical backgrounds) have been able to successfully complete the course without a grade penalty. That is, their work is complete and on time. Prior to Fall 1996, all non-traditional students taking the course had either dropped the course or were administratively withdrawn. Since Fall 1996, five non-traditional students successfully completed the course with a grade of $\mathrm{B}$ or better. Two of these 
Table 3. Course Descriptions, Present (since Fall 1996)

\begin{tabular}{|c|c|c|}
\hline $\begin{array}{c}\text { Course } \\
\text { Number and } \\
\text { Title } \\
\end{array}$ & Course Objectives & Course Topics \\
\hline $\begin{array}{l}\mathrm{IE} 4663, \text { Systems } \\
\text { Analysis Using } \\
\text { Simulation }\end{array}$ & $\begin{array}{l}\text { A student completing this course should understand } \\
\text { (i) the use of simulation in systems analysis, (ii) } \\
\text { simulation terminology, (iii) discrete-event } \\
\text { simulation, (iv) the need for simulation output } \\
\text { analysis, and (v) the simulation language ARENA. }\end{array}$ & $\begin{array}{l}\text { Review of systems analysis, queuing } \\
\text { systems and statistics, basic concepts of } \\
\text { simulation modeling and discrete-event } \\
\text { simulation, introduction to ARENA and } \\
\text { animation, network modeling techniques, } \\
\text { introduction to simulation output } \\
\text { analysis. }\end{array}$ \\
\hline $\begin{array}{l}\text { IE5663, } \\
\text { Simulation I }\end{array}$ & $\begin{array}{l}\text { A student completing this course should (i) } \\
\text { understand the implementation of a simulation study } \\
\text { through a course project, (ii) understand simulation } \\
\text { terminology and discrete-event logic, (iii) be able to } \\
\text { use the simulation language ARENA, and (iv) be able } \\
\text { to perform simulation output analysis on terminating } \\
\text { and non-terminating systems. }\end{array}$ & $\begin{array}{l}\text { Implementing discrete-event simulation } \\
\text { logic; basic concepts of simulation } \\
\text { modeling; introduction to ARENA and } \\
\text { animation; perform a Simulation Study; } \\
\text { data collection and input modeling; } \\
\text { advanced simulation modeling and } \\
\text { animation, simulation output analysis, } \\
\text { comparing alternative system designs. }\end{array}$ \\
\hline $\begin{array}{l}\text { IE5573, } \\
\text { Statistical } \\
\text { Analysis of } \\
\text { Simulation }\end{array}$ & $\begin{array}{l}\text { A student completing this course should have a } \\
\text { thorough understanding of the probabilistic and } \\
\text { statistical aspects in the design and analysis of } \\
\text { stochastic simulations: random number generation, } \\
\text { random variate generation, input modeling, output } \\
\text { analysis (including time series models and spectral } \\
\text { analysis), ranking and selection and variance } \\
\text { reduction techniques }\end{array}$ & $\begin{array}{l}\text { Input modeling, generating random } \\
\text { variates, discrete-event simulation, output } \\
\text { analysis, comparing alternative systems, } \\
\text { variance reduction techniques, } \\
\text { experimental design and optimization. }\end{array}$ \\
\hline $\begin{array}{l}\text { IE6663 } \\
\text { Simulation II }\end{array}$ & $\begin{array}{l}\text { A student completing this course should have an in- } \\
\text { depth understanding of advanced simulation } \\
\text { concepts, including discrete-event modeling, } \\
\text { continuous modeling, advanced animation, } \\
\text { operation of a simulation language and the basic } \\
\text { concepts of how a language is constructed. They } \\
\text { should be able to construct advanced models that can } \\
\text { address a variety of specific applications with only } \\
\text { changes in model data. }\end{array}$ & $\begin{array}{l}\text { Discrete-event modeling, continuous } \\
\text { modeling, advanced animation, advanced } \\
\text { model design and construction, and } \\
\text { simulation language architectures. }\end{array}$ \\
\hline
\end{tabular}

students went on to complete their master's thesis in simulation analysis.

6. Student (course) projects from the course itself have led to the development of three software packages for performing simulation output analysis via Visual Basic. One of these packages is now used as courseware (software utilized by the students for inclass and out-of-class activities) for the first, second and third levels of the pyramid.

7. The course is now portable and can be easily segmented. For example, a one-credit version of the course was offered at the University of Tulsa in June 1999. Because of the modularity of the web tools, the one-credit version took only a week to prepare and set up on the web.

\section{Disadvantages of Web-based Technology}

Online technologies are not without their disadvantages. While the burden has been eased on student learning and their out-of-class activities, the faculty are now tasked with an increased load of supporting online courses and utilizing web-based technologies. As shown in Tables 1 and 2, switching from a traditional, lecture-based delivery system to an online classroom requires changes in how courses are developed and taught. Figure 2 reveals that with the traditional delivery system, about $75 \%$ of the in-class activities involved students taking notes while the instructor lectured, and left on the average $25 \%$ of the in-class activities for quizzes, exams and questions / discussions. However, with the online/multimedia delivery system only about $5 \%$ of the in-class activities involve the students taking notes during the lecture (since all notes are available to the student during the class time) with approximately $10 \%$ of the time devoted to lecturing. The majority of the in-class activities now involve interactive learning (where the faculty presents students with problems 
Figure 2. Impact of Web-based delivery system on in-class activities

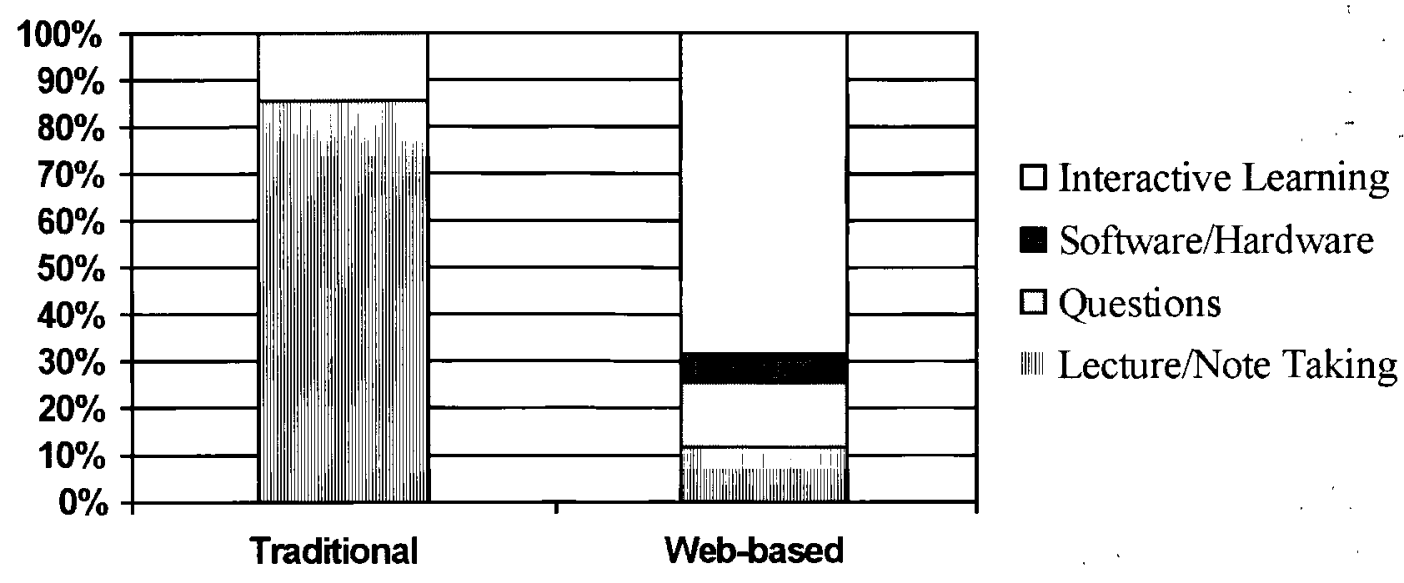

that must be solved within the class period). Taking online quizzes and exams encompasses another $12.5 \%$ of the in-class activities and 5\% involves solving software and hardware issues.

Notice that the shift to computer-based classrooms also shifts the burden of software support into the classroom and onto the faculty (if and when computer hardware or software failures occur). As a result, faculty may require teaching assistants to be in the classroom during the class period. Consequently, the online classroom is also changing the role that teaching assistants play in the simulation courses.
A ramification of offering online courses can be seen in the administrative load of developing and maintaining the courses and courseware (software utilized in the classroom), as shown in Table 4. On the average, online grading (including developing electronic exams and assignments) takes three times the effort of traditional grading systems, and preparing online lectures (with text only) requires from 8 to 16 hours of faculty time. Additionally, students rely on e-mail as their main form of communication with the faculty. Thus, office hours are essentially becoming 24 hours a day. The net effect is that faculty offering

Table 4. Web-based development and delivery tasks and time

\begin{tabular}{|c|c|}
\hline \multicolumn{1}{|c|}{ Development Task } & Development Time \\
\hline Lecture with & $6-8$ hours \\
Text & $9-16$ hours \\
Graphics and Images & $20-40$ hours \\
Animation & \\
Text & $8-10$ hours \\
Graphics and Images & $16-20$ hours \\
Animation & $16-40$ hours \\
Interactive Features & $20-80$ hours \\
Text & $30-45$ minutes \\
Graphics and Images & $1-2$ hours \\
Animation & $2-4$ hours \\
\hline Assignment with & 45 minutes-2 hours \\
\hline Assignment Solution & $1-2$ hours \\
\hline Exam Delivery Task & $20-40$ hours \\
\hline Exam Solution & Time \\
\hline On-line Quiz (self-paced) & 15 minutes-1 hour per question \\
\hline \multicolumn{1}{|c|}{ Delive minutes per student } \\
\hline On-line Grading & $30-45$ minutes per student \\
Assignments & 30 minutes-2 hours per week \\
Exams & 30 minutes-1 hour per assignment \\
\hline Answering e-mails & $15-45$ minutes per assignment \\
\hline Modify Assignments & \\
\hline Modify Solutions &
\end{tabular}


online courses can expect to spend a minimum of three full months developing the course and $20-50 \%$ more time (over traditional courses) administering the course (answering e-mails, online grading, etc.) during the semester.

\section{Future Developments}

The simulation pyramid will institute its first laptop course in Fall 2001 with Systems Analysis using Simulation (IE4663). The COE's laptop program requires all application software to reside locally on the laptop, and the course residing on the world-wide-web. Consequently, access to professional licenses of simulation software (currently residing on the network) for performing in-class activities is the next issue that needs to be addressed. In addition, more quantitative analysis must be performed on the web-technology to determine the value added. For example, questions that need to be explored include: does student learning and comprehension of a topic increase enough to justify the faculty time required to add animation to a topic? The difficulty lies in providing a test-bed for the analysis. If two sections of the course are taught, where one is web-based and the other is traditional, it is easier to generate quantitative results. So far, the analysis is based on past student performance versus today's student performance. A better rubric for testing the impact of web-technology needs to be established.

\section{References}

[1] Baker, D. (1990). "Gender Differences in Science: Where They Start and Where They Go." Paper presented at the 1990 Meeting of the National Association for Science Teaching and Research (April 1990).

[2] Johnson, R. T. and Johnson, D. W. (1993). "Cooperative Learning and the Achievement Socialization Crisis in Science and Math Classrooms." Students and Science Learning. A. B. Champagne and L. E. Horning (Eds.). Washington.

[3] Farell, M. L. (1984), "A review of research on styles: Implications for the development and implementation of CAI for bilingual students." Conference Proceedings: Delivering academic excellence to culturally diverse populations. T.C. Bilotta (Ed.). Farleigh Dickinson University. Teaneck, NJ. Pp 37-43.

[4] Ramirez III, M. and D. R. Price-Williams (1974), "Cognitive styles of children of three ethnic groups in the United States," Journal of Cross-Cultural Psychology. Vol. 5, pp 212219.
Mary Court is an associate professor in the School of Industrial Engineering at the University of Oklahoma. She received her BSIE from Rensselaer Polytechnic Institute in 1984, MS in Operations Management from Rensselaer Polytechnic Institute in 1989, and PhD in Decision Sciences and Engineering Systems from Rensselaer Polytechnic Institute in 1993. Her professional experience includes working for General Dynamics from 1987 to 1989 as a manufacturing, systems and industrial engineer and as an industrial engineer for Sony Corporation of America from 1984 to 1987. Dr. Court was a National Defense Science and Engineering Grant Fellow from 1989 to 1992, and received the Del and Ruth Krager Dissertation Award from Rensselaer Polytechnic Institute in May 1994. She was a Junior Faculty Research Fellow at the University of Oklahoma in 1994, and was named as a 1997 Outstanding Young American. Her research areas lie in the development of simple, accurate statistical tools to remove human subjectivity from simulation output analysis and the use of electronic technology for supporting student-based learning. 